\title{
Brazilian Kefir-Fermented Sheep's Milk, a Source of Antimicrobial and Antioxidant Peptides
}

\author{
Meire dos Santos Falcão de Lima ${ }^{1,2}$ (1) - Roberto Afonso da Silva ${ }^{2} \cdot$ Milena Fernandes da Silva $^{3}$. \\ Paulo Alberto Bezerra da Silva ${ }^{4} \cdot$ Romero Marcos Pedrosa Brandão Costa ${ }^{1}$. José António Couto Teixeira ${ }^{5}$. \\ Ana Lúcia Figueiredo Porto ${ }^{1,2}$. Maria Taciana Holanda Cavalcanti ${ }^{1,2}$
}

Published online: 28 December 2017

(C) Springer Science+Business Media, LLC, part of Springer Nature 2017

\begin{abstract}
Fermented milks are a source of bioactive peptides and may be considered as functional foods. Among these, sheep's milk fermented with kefir has not been widely studied and its most relevant properties need to be more thoroughly characterized. This research study is set out to investigate and evaluate the antioxidant and antimicrobial properties of peptides from fermented sheep's milk in Brazil when produced by using kefir. For this, the chemical and microbiological composition of the sheep's milk before and after the fermentation was evaluated. The changes in the fermented milk and the peptides extracted before the fermentation and in the fermented milk during its shelf life were verified. The antimicrobial and antioxidant activities of the peptides from the fermented milk were evaluated and identified according to the literature. The physicochemical properties and mineral profile of the fermented milk were like those of fresh milk. The peptide extract presented antimicrobial activity and it was detected that 13 of the 46 peptides were able to inhibit the growth of pathogenic microorganisms. A high antioxidant activity was observed in the peptides extracted from fermented milk $(3.125 \mathrm{mg} / \mathrm{mL})$ on the 28th day of storage. Two fractions displayed efficient radical scavenging properties by DPPH and ABTS methods. At least 11 peptides distributed in the different fractions were identified by tandem mass spectrometry. This sheep's milk fermented by Brazilian kefir grains, which has antioxidant and antimicrobial activities and probiotic microorganisms, is a good candidate for further investigation as a source for bioactive peptides. The fermentation process was thus a means by which to produce potential bioactive peptides.
\end{abstract}

Keywords Bioactive peptides $\cdot$ Sheep milk $\cdot$ Fermented milk $\cdot$ Kefir $\cdot$ Antioxidant potential $\cdot$ Antimicrobial potential

Meire dos Santos Falcão de Lima

meirefalcao.ufrpe@gmail.com

1 Department of Morphology and Animal Physiology, University Federal Rural of Pernambuco-UFRPE, Rua Dom Manoel de Medeiros, s/n, Dois Irmãos, Recife, PE 52171-900, Brazil

2 Keizo Asami Immunopathology Laboratory, University Federal of Pernambuco-UFPE, Avenida Professor Moraes Rêgo, 1235- Cidade Universitária, Recife, PE 50670-901, Brazil

3 Biological Sciences Center, University Federal of Pernambuco-UFPE, Avenida Professor Moraes Rêgo, 1235- Cidade Universitária, Recife, PE 50670-901, Brazil

4 Department of Fundamental Chemistry, University Federal of Pernambuco-UFPE, Avenida Professor Moraes Rêgo, 1235- Cidade Universitária, Recife, PE 50670-901, Brazil

5 Institute for Biotechnology and Bioengineering, Centre of Biological Engineering, Universidade do Minho, Campus de Gualtar, 4710-057 Braga, Portugal

\section{Introduction}

Kefir is a fermented milk product that has been historically used to promote and maintain good health, especially in Caucusus [1]. Kefir is produced using different types of milk [2]. It is easily digested and is the best known source of potential probiotic [3]. Kefir is produced by the fermentative activity of kefir grains, a natural starter culture, which contains a diverse range of inherent lactic acid bacteria, acetic acid bacteria and yeasts in a polysaccharide matrix of semi-hard granules [4].

Some health promoting effects could indeed be caused by potential probiotics. While the microorganisms themselves have the most important impact, exo-polysaccharide kefiran and other byproducts of the microbiological metabolism need to be taken into account [5]. However, less is known about the role of bioactive peptides in kefir, which can be formed during fermentation [6]. 
Milk fermented by kefir acts in the digestive system and initially promotes protection against caries [7]; in the stomach, it has a gastroprotective effect on ulcers [8], and contributes to the eradication of Helicobacter pylori when used in therapy [9]; it increases immunity in the gut [10], by increasing enzyme activity and the absorption of nutrients [11], and protects against Giardia intestinalis infection [12]. In the circulatory system, it actively promotes hypocholesterolemic effects [13] and assists in the endothelial restoration of vessels of hypertensive mammals [14].

Peptides have received attention as physiologically active fragments within the sequence of food proteins [14]. The proteolytic breakdown of milk proteins generates a number of peptides endowed with various biological properties, namely activities that are antimicrobial [15], antioxidant [16], antihypertensive [17], antithrombotic and immuno-modulatory [18, 19]. According to Dallas et al. [20] the presence of 29 bioactive peptides released from bovine milk protein by kefir microorganisms, which are classified as functional peptides, demonstrated antibacterial, antihypertensive, opioid and antioxidative functions and of these, 26 were present in the Kefir samples that derived from as1-, as2-, $\beta$ - and $\mathrm{K}$-casein. Six functional peptides were more abundant in Kefir samples than the controls.

The peptides present in yogurt production from cow, goat and buffalo milk had strong antioxidant activities which significantly increased during their fermentation. These same bioactive compounds were also able to inhibit Staphylococcus aureus and Bacillus cereus [21].

However, although the hydrolysis of the proteins in sheep milk and the biological activities of these proteins in cheese have been investigated, there is little information available on fermented sheep milk [17]. Akalin, 2014 [22] reports the presence of 4 bioactive peptides with antimicrobial activity in vitro, obtained from $\alpha$ s2 milk casein of sheep milk and from pepsin.

The literature is scarce with regard to its having references to data on bioactive peptides obtained from fermented sheep's milk, very probably because the availability of this product on the market is restricted. Therefore, this study set out to evaluate the antioxidant and antimicrobial properties of watersoluble peptides (WSP) obtained from sheep's milk fermented by Brazilian kefir grains, and the quality of kefir-type fermented milk during storage.

\section{Materials and Methods}

\section{Chemicals}

All chemicals and reagents were of analytical grade and purchased from Himedia (Mumbai, India) or Sigma-Aldrich Chemie GmbH (Steinheim, Germany).

\section{Fermented sheep's milk}

Sheep milk was purchased from a farm in the town of Vitória de Santo Antão - PE/Brazil. The quality of the milk samples was determined using a Bentley Combi 2300 (Bentley Instruments Incorporated, Chaska, MN, USA) to find the somatic cell count and to determine the milk components on a single device. The sample was collected once and subsequently, all analyses were performed. Brazilian kefir grains were obtained from a private household in Pernambuco (Brazil). They were washed with distilled water and inoculated in pasteurized sheep milk $\left(65^{\circ} \mathrm{C}\right.$ for 30 min, then chilled to $7^{\circ} \mathrm{C}$ ). After each elaboration process, the grains were then separated from the fermented milk by filtration through a plastic sieve and washed with ultrapure water before incubating the next culture. This fermented milk was made by adding an inoculum consisting of $5 \%$ $(w / w)$ kefir grains. After incubation at $20{ }^{\circ} \mathrm{C}( \pm 2)$ for 45 $48 \mathrm{~h}$ until $\mathrm{pH} 4.5$, the grains were separated from the fermented milk by filtration through a plastic sieve and washed prior to incubating the next culture.

\section{Chemical and microbiological compositions}

The chemical and microbiological analyses were performed on the fermented milk after 48 hours of fermentation. The protein, fat, ash, moisture, general carbohydrates and calorific contents were determined [23]. The $\mathrm{Na}, \mathrm{K}, \mathrm{Mg}$ and $\mathrm{Ca}$ contents were quantified using an atomic absorption spectrophotometer (model AA240FS; Varian, Palo Alto, California, USA), according to Santos et al. [24].

The presumptive characterization of the microorganisms stored for 28 days at $4{ }^{\circ} \mathrm{C}$ was carried out with the purpose of identifying the types of microorganisms belonging to the fermentation and if they occur during the storage period. A presumptive characterization was conducted by means of diluting and plating the fermented milk in specific media. The methodology of Miguel et al. [4], with some modifications, was used to test for presumptive Lactococcus sp. and Lactobacillus sp.; the dilutions were plated and incubated under aerobic conditions at $\mathrm{pH} 7$ for $2 \mathrm{~d}$ at $30{ }^{\circ} \mathrm{C}$ and under anaerobic conditions at $\mathrm{pH} 5.5$ for 5 days at $37^{\circ} \mathrm{C}$ (pour plate) on Man-Rogosa-Sharpe agar (MRS agar, Himedia ${ }^{\circledR}$, Mumbai, India), respectively. The yeast counts were determined in accordance with Grønnevik, Falstad and Narvhus, [25] Sabouraud agar (Himedia ${ }^{\circledR}$, Mumbai, India) plates were incubated for 5 days at $30^{\circ} \mathrm{C}$. All the microbiological count results are expressed as $\log _{10} \mathrm{CFU} / \mathrm{mL}$. The experimental results were obtained at $1,7,14,21$ and 28 days of storage at $4{ }^{\circ} \mathrm{C}$ for the microbiological counts and were expressed as $\log _{10}$ $\mathrm{CFU} / \mathrm{mL}$. The assays were carried out in triplicate, on samples that had been stored for up to 28 days at $4{ }^{\circ} \mathrm{C}$. 
The presence of coliforms and Escherichia coli were determined according to AOAC [23], using pasteurized and fermented milk after 1 and 28 days of storage at $4{ }^{\circ} \mathrm{C}$.

\section{Shelf life of the fermented milk}

To evaluate the shelf life of the fermented milk, the titratable acidity $(\mathrm{g} / \mathrm{L})$ and $\mathrm{pH}$ of all samples were analyzed. The $\mathrm{pH}$ was measured using a $\mathrm{pH}$ analyzer (Hanna Instruments Inc., model HI 2210, Woonsocket, RI, USA). The acidity was determined and expressed as grams of lactic acid per liter of product [23].

\section{Extraction of water-soluble peptides}

The water-soluble peptides were extracted at 1, 7, 14, 21 and 28 days of storage at $4{ }^{\circ} \mathrm{C}$ to evaluate the changes in the extracts, according to Pritchard, Phillips and Kailasapathy [26]. Two tubes each containing $20 \mathrm{~mL}$ of fermented milk and $20 \mathrm{~mL}$ of distilled water were vortexed. They were then placed in a $40{ }^{\circ} \mathrm{C}$ water bath for $1 \mathrm{~h}$, and centrifuged at $14.560 \times \mathrm{g}$ for $20 \mathrm{~min}$ at $4{ }^{\circ} \mathrm{C}$ (Hermle Labortechnik Centrifuge $326 \mathrm{HK}$, Wehingen, Germany). The pellet was discarded. The supernatant was re-centrifuged and subsequently filtered through $\mathrm{N}^{\circ} 4$ Whatman filter paper. The filtrate was stored at $-20{ }^{\circ} \mathrm{C}$ until further use. The protein concentrations were determined using a BCA Protein Assay Kit (Pierce, Rockford, IL, USA). Bovine serum albumin was used as a standard.

Concentrations of $25,12.5,6.25$ and $3.125 \mathrm{mg}$ of lyophilized samples of WSP per $\mathrm{mL}$ of distilled water were used for 2,2-azino-bis-(3-ethylbenzothiazoline)-6-sulfonic acid (ABTS) and1,1-Diphenyl-2-picryl-hydrazyl (DPPH) antioxidant assays, and the final concentration of $25 \mathrm{mg} / \mathrm{mL}$ was evaluated for antimicrobial activity. All assays were performed at least in triplicate $(n=3)$.

\section{Profile of the peptides in fermented milk using reversed-phase high-performance liquid chromatography}

The samples were prepared after diluting $2 \mathrm{mg}$ of the crude peptides extracted from fermented milk samples during storage at $4{ }^{\circ} \mathrm{C}$ for $1,7,14,21$ and 28 days in $200 \mu \mathrm{L}$ of Eluent $\mathrm{A}$ and $200 \mu \mathrm{L}$ of Eluent B. Eluent A was $0.1 \%(v / v)$ TFA $(99.5 \%$ Tedia Company Inc., Fairfield, OH, USA) in ultra-pure water, and Eluent B was $0.09 \%(v / v)$ TFA in acetonitrile (HPLC grade, MerckK GaA, Darmstadt, Germany) in a 60:40 mixture with ultrapure water.

The high-performance liquid chromatography (RP-HPLC) system used for the analyses was equipped with two model LC6AD solvent pumps and a refractive index detector (RID-10A, Shimadzu Corp., Kyoto, Japan) and this system was used to monitor the absorbance of the eluate at $278 \mathrm{~nm}$ (Papadimitriou et al., 2007) [17]. The samples were injected using a Rheodyne 7125 i automatic injector (Rheodyne Inc., Cotati, CA, USA) with a $20-\mu \mathrm{L}$ loop. To determine the chromatographic profile, use was made of a Luna $5 \mu \mathrm{m} \mathrm{C-18} \mathrm{80A} \mathrm{analytical} \mathrm{column}$ $(150 \times 4.6 \mathrm{~mm} \times 5 \mu \mathrm{m}$, Phenomedex, Big Lake, MN, USA) equipped with a Luna C-18 21-mm pre-column.

The samples were evaluated at $30^{\circ} \mathrm{C}$ at a flow rate of 0.8 $\mathrm{mL} / \mathrm{min}$ using the following protocol: Eluent A, 0 to $5 \mathrm{~min}$ of a linear gradient from $0 \%$ to $20 \%$ of Eluent B; 5 to $10 \mathrm{~min}$ of a linear gradient from $20 \%$ to $0 \%$ of Eluent B; 10 to $30 \mathrm{~min}$ of a linear gradient from $0 \%$ to $50 \%$ of Eluent B; and 30 to $40 \mathrm{~min}$ of a linear gradient from $50 \%$ to $100 \%$ of Eluent B. The data acquisition software and processing equipment included with the system were used.

\section{Maldi-TOF analysis of the WSP}

The peptide profiles were analyzed by means of matrixassisted laser desorption/ionization time-of-flight mass spectrometry (Maldi-TOF-MS) using an Autoflex III mass spectrometer (Bruker Daltonics, Bremen, Germany) equipped with a $355 \mathrm{nmNd}$ : YAG laser. The sample was mixed with matrix solution comprising $10 \mathrm{mg} / \mathrm{mL}$ of $\alpha$-cyano-4hydroxycinnamic acid in $50 \%$ acetonitrile with $0.1 \%$ trifluoroacetic acid. Subsequently, $0.5 \mu \mathrm{L}$ of this mixture was spotted onto a MALDI target plate (MTP 384 ground steel, Bruker Daltonics, Bremen, Germany) and dried at room temperature. The mass spectra were acquired in positive reflection mode using an acceleration voltage of $19 \mathrm{kV}$ and a laser frequency of $100 \mathrm{~Hz}$. The ion detection range was $\mathrm{m} / \mathrm{z}$ 0.7 to $3 \mathrm{KDa}$. External calibration was performed using a standard mixture of peptides. The data were acquired using Flex Control software, and the spectra were processed using Flex Analysis One software (Version 3.0, Bruker Daltonics).

\section{Determination of antimicrobial activity}

The microorganisms used to determine antimicrobial activity included Escherichia coli ATCC 25922, Klebsiella pneumoniae ATCC 29665, Pseudomonas aeruginosa ATCC 27853, Enterococcus faecalis ATCC 6057, Bacillus cereus ATCC 33019, Bacillus subtilis ATCC 6633 and Staphylococcus aureus ATCC 6538. The pre-inoculum for each standard strain was prepared in Müller Hinton broth. All strains were aerobically incubated at $37{ }^{\circ} \mathrm{C}$ for $\sim 18 \mathrm{~h}$. The biomass concentration was determined by measuring the turbidity of the suspension at $595 \mathrm{~nm}$ (Microplate Lector LM-LGC, LGC Biotecnologia Ltda, São Paulo, Brazil) and then converted to colony-forming units $\left(1.5 \times 10^{8} \mathrm{CFU} / \mathrm{mL}\right)$ using appropriate calibration curves (turbidity equivalent to 0.5 on the McFarland scale). One CFU represents a viable cell that is able to promote bacterial growth. The reaction mixture 
containing $50 \mu \mathrm{L}$ of the fermented peptide extract and $50 \mu \mathrm{L}$ of the bacterial suspension was evaluated after incubation for $24 \mathrm{~h}$ at $37^{\circ} \mathrm{C}$. Bacterial growth was monitored by reading at $595 \mathrm{~nm}$ [26]. All experiments were performed in triplicate in a 96-well microplate $\left(\mathrm{NUNC}^{\circledR}\right)$, and to prevent problems with sedimentation of the bacterial culture, the microplate was stirred for 30 seconds before reading. The result was determined as the percentage of inhibition of bacterial growth based on negative control medium without bacteria and positive control medium with bacteria were the controls used to determine growth.

\section{Antioxidant assays}

\section{Antioxidant activity of WSP samples using ABTS}

The oxidation reaction was prepared using a $7 \mathrm{mM}$ ABTS stock solution with $140 \mathrm{mM}$ potassium persulfate (final concentration). The mixture was incubated in the dark at room temperature $\left(23-25^{\circ} \mathrm{C}\right)$ for $12-16 \mathrm{~h}$ (the time required for radical formation) prior to use. The ABTS solution was diluted in ethanol to an absorbance of $0.7( \pm 0.02)$ at $734 \mathrm{~nm}$. The antioxidant activity was performed using $30 \mu \mathrm{L}$ aliquots of the samples mixed with $3 \mathrm{~mL}$ diluted ABTS solution [27]. The absorbance at $734 \mathrm{~nm}$ was measured at $6,30,60,90,150$ and 180 min [28]. Trolox (6-hydroxy-2, 5,7,8tetramethylchroman-2-carboxylic acid) was used as the reference standard. The values were calculated and expressed as percentages of antioxidant activity in accordance with Eq. (1):

$\% \mathrm{AA}=\frac{\mathrm{Absi}-\mathrm{Abss}}{\mathrm{Absi}} \times 100$

where $\mathrm{Abs}_{i}$ is the initial absorbance (ABTS solution) and $\mathrm{Abs}_{s}$ is the absorbance of the mix (ABTS solution + sample).

\section{Radical scavenging activity of WSP samples using DPPH}

The DPPH radical-scavenging activity was determined by applying the method developed by Brand-Williams, Cuvelier and Berset [29], modified by Fukumoto and Mazza [30]. In a 96-well microplate, $22 \mu \mathrm{L}$ of each extract at various concentrations were mixed with $200 \mu \mathrm{L}$ of a DPPH solution $(25 \mathrm{mg} /$ L) which is prepared fresh daily. Because of the turbidity of the extracts, the blanks were prepared after mixing $22 \mu \mathrm{L}$ of extract at various concentrations with $200 \mu \mathrm{L}$ of ethanol. The reaction was developed for $2 \mathrm{~h}$ in the dark at room temperature, and subsequently the absorbance was read at 450 and $595 \mathrm{~nm}$ using a Microplate Lector LM-LGC (LGC Biotechnologies Ltda, São Paulo, Brazil). Ascorbic acid was used as a positive control. The DPPH concentration in the reaction medium was calculated from a calibration curve
( $n=8 ; r=0.991)$ which was determined by using linear regression to further deduce the percentage of remaining DPPH (\% DPPH). The percentage of reduction of DPPH was calculated according to Eq. (2):

$\% \mathrm{AA}=\frac{A b s i-A b s s}{A b s i} \times 100$

where $\mathrm{Abs}_{i}$ is the initial absorbance (ethanolic solution + $\mathrm{DPPH})$ and $\mathrm{Abs}_{s}$ is the absorbance of the mix (DPPH + sample).

\section{Statistical Analysis}

The data were subjected to analysis of the variance of the mean values for the individual samples and compared using an ANOVA with a significance level of 0.05 for which Minitab software (Palo Alto, CA, USA) was used.

\section{Results}

\section{Chemical and microbiology characterization of sheep milk}

An analysis of raw sheep milk showed that it has characteristics that fit into the industrial production of a fermented dairy product (data not shown). After determining the quality of raw milk, this milk was pasteurized and then kefir grains were added and the mixture was fermented. Chemical analysis revealed that the levels of protein, fat, general carbohydrates, calorific content, ash, moisture, mineral contents did not differ significantly $(p>0.05)$ after the fermentation using kefir (Table 1).

However, the lactose content of sheep milk fermented using kefir did differ significantly $(p<0.05)$ after the fermentation: it decreased $38.13 \%$ compared with the initial level $(4.72 \pm 0.42)$ in the milk used. The values of general carbohydrates $(5.06 \pm$ $0.25 \%)$ differed from the lactose values $(4.72 \pm 0.42 \%)$ of the pasteurized milk. This is because an analysis, in addition to the analysis on lactose, was conducted on other carbohydrates such as oligosaccharides produced by autochthonous bacteria present in milk, as well as the monosaccharides, glucose and galactose, which form from the hydrolysis of lactose.

The fermented milk lactose content $(2.92 \pm 0.24 \%)$ decreases significantly because kefir microorganisms use lactose as the main carbohydrate source in order to ferment milk. The general content of carbohydrates present in the fermented product is still large $(4.11 \pm 0.62 \%)$, because in this milk there are residues of the hydrolysis of lactose and prebiotics such as the kefiran produced by kefir grains.

The results about microorganisms in fermented milk are shown in Fig. 1. 
Table 1 Chemical composition of pasteurized and fermented milk after $48 \mathrm{~h}$ of fermentation

\begin{tabular}{lcc}
\hline Centesimal composition & Pasteurized milk & Fermented milk \\
\hline Protein $(\mathrm{g})$ & $5.65 \pm 0.08$ & $5.71 \pm 0.25$ \\
Fat $(\mathrm{g})$ & $5.05 \pm 0.42$ & $5.21 \pm 0.51$ \\
Lactose $(\mathrm{g})$ & $4.72 \pm 0.42$ & $2.92 \pm 0.24^{*}$ \\
Ash $(\mathrm{g})$ & $0.91 \pm 0.05$ & $0.94 \pm 0.03$ \\
General carbohydrate $(\mathrm{g})$ & $5.06 \pm 0.25$ & $4.11 \pm 0.62$ \\
Moisture $(\mathrm{g})$ & $83.30 \pm 0.55$ & $83.99 \pm 0.99$ \\
Calories value (Kcal) & $87.98 \pm 3.84$ & $84.86 \pm 3.20$ \\
$\mathrm{Na}(\mathrm{mg} / \mathrm{L})$ & $413.80 \pm 46.11$ & $401.20 \pm 39.53$ \\
$\mathrm{~K}(\mathrm{mg} / \mathrm{L})$ & $12.31 \pm 209$ & $11.188 \pm 728$ \\
$\mathrm{Mg}(\mathrm{mg} / \mathrm{L})$ & $213.37 \pm 17.04$ & $206.04 \pm 8.40$ \\
$\mathrm{Ca}(\mathrm{mg} / \mathrm{L})$ & $1865.7 \pm 79.0$ & $1765.3 \pm 106.4$ \\
\hline
\end{tabular}

The results are the average values of triplicate analyses \pm standard deviation

*Values are significantly different $(p>0.05)$ according to an ANOVA test

The bacterial population was relatively stable during the storage period (28 days). The presumptive count of Lactobacillus and Lactococcus was approximately $11 \log _{10}$ $\mathrm{CFU} / \mathrm{mL}$ from the first day of fermentation until the 28th day of storage.

The product prepared in this study obtained a yeast count of $8 \log _{10} \mathrm{CFU} / \mathrm{mL}$ on the first day of storage which decreased during storage to $6.6 \log _{10} \mathrm{CFU} / \mathrm{mL}$ at the end of 28 days.

\section{Shelf life of fermented milk}

The $\mathrm{pH}$ and titratable acidity values of pasteurized sheep milk and fermented sheep milk using kefir grains during the 28 days of storage at $4^{\circ} \mathrm{C}$ are shown in Fig. 2 .

The mean $\mathrm{pH}$ and acidity in pasteurized milk were $6.57 \pm$ 0.07 and $2.73 \pm 0.28 \mathrm{~g} / \mathrm{L}$ of lactic acid, respectively. The physicochemical results show $\mathrm{pH}$ decreased $(2.11 \mathrm{lb})$ and

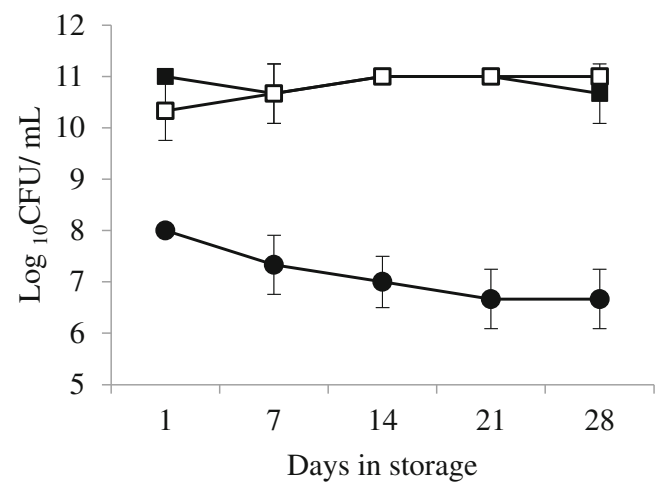

Fig. 1 Counts of microorganism of kefir-type fermented sheep's milk after fermentation and during the storage. Error bars show the average of three independent experiments. Lactobacillus (black square), Lactococcus (white square), and yeast (black circle) during storage at $4{ }^{\circ} \mathrm{C}$

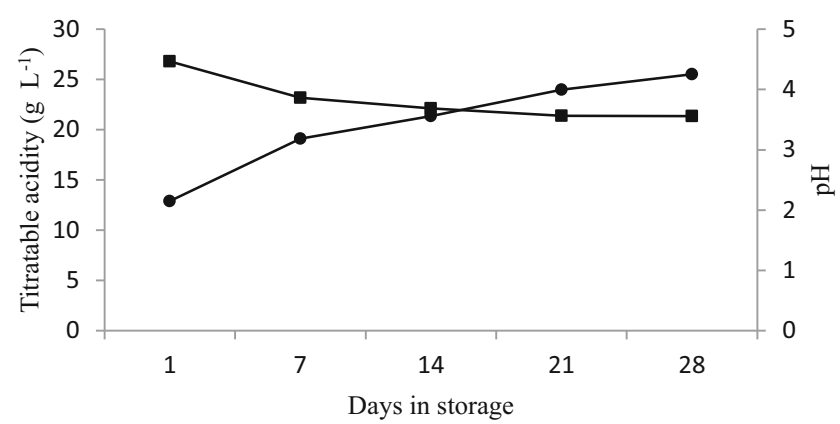

Fig. 2 Changes of $\mathrm{pH}$ and titratable acidity of pasteurized sheep's milk (day 0 ) and kefir-type fermented sheep's milk during the 1, 7, 14, 21, and 28 days of storage at $4{ }^{\circ} \mathrm{C} . \mathrm{pH}$ (black square) and titratable acidity (black circle)

the acidity increased $(10.2 \mathrm{~g} / \mathrm{L})$ as expected during fermentation of the milk by kefir grains. The $\mathrm{pH}$ decreased slowly $(0.91$ lb) and the acidity increases similarly fermentation $(12.6 \mathrm{~g} / \mathrm{L})$ during storage for 28 days at $4{ }^{\circ} \mathrm{C}$.

\section{Peptide profile of fermented milk using RP-HPLC}

The RP-HPLC profile of aqueous peptide extracts from sheep's milk after pasteurization and samples of aqueous peptide extracts from fermented sheep's milk during 28 days of storage at $4{ }^{\circ} \mathrm{C}$, are presented in Fig. 3 .

The chromatographic profiles obtained from this study showed a difference between peptide extracts of pasteurized milk and peptide extracts of fermented milk after 1, 7 and 28 days of storage at $4{ }^{\circ} \mathrm{C}$.

\section{Peptides identified using MALDI-TOF analyses}

A more detailed peptide analysis was subsequently performed by direct MALDITOFMS measurement at an $\mathrm{m} / \mathrm{z}$ ranging from 700 to $3000 \mathrm{Da}$ (Fig. 4).

Most of the signals were detected in a range from 703 to 1881 Da, i.e., corresponding to peptide lengths of approximately 6-17 amino acids. In the samples with pasteurized sheep milk, 13 peptides could be detected, whereas 46 signals were observed in kefir-fermented sheep milk (Fig. 4).

Table 2 displays the peptides identified in the water-soluble extracts of kefir-fermented sheep milk according to the mass spectrometry spectrum compared to literature.

\section{Antimicrobial activity}

Table 3 presents the results observed for the aqueous peptide extract obtained from pasteurized and fermented milk during the storage at a final concentration of $25 \mathrm{mg} / \mathrm{mL}$ with regard to its antimicrobial activity.

The antimicrobial activity of peptides extracted from pasteurized milk against Bacillus cereus ATCC 33019 , Pseudomonas aeruginosa ATCC 27853, and Bacillus subtilis 


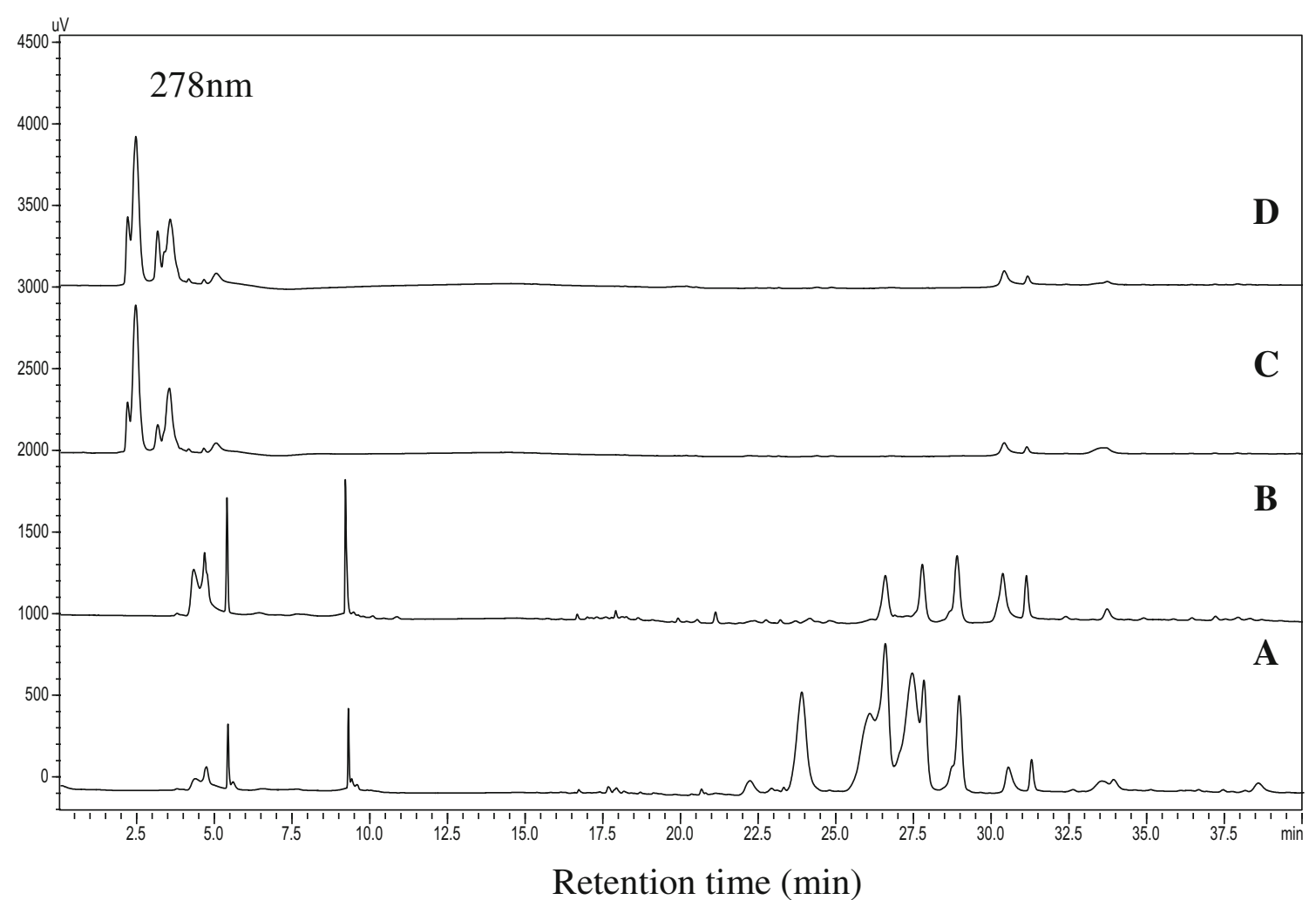

Fig. 3 RP-HPLC chromatograms present the changes in the profile of aqueous peptide extract of pasteurized sheep's milk (A) and after storage at $4{ }^{\circ} \mathrm{C}$ for 1 (B), 7 (C), and 28 days (D)
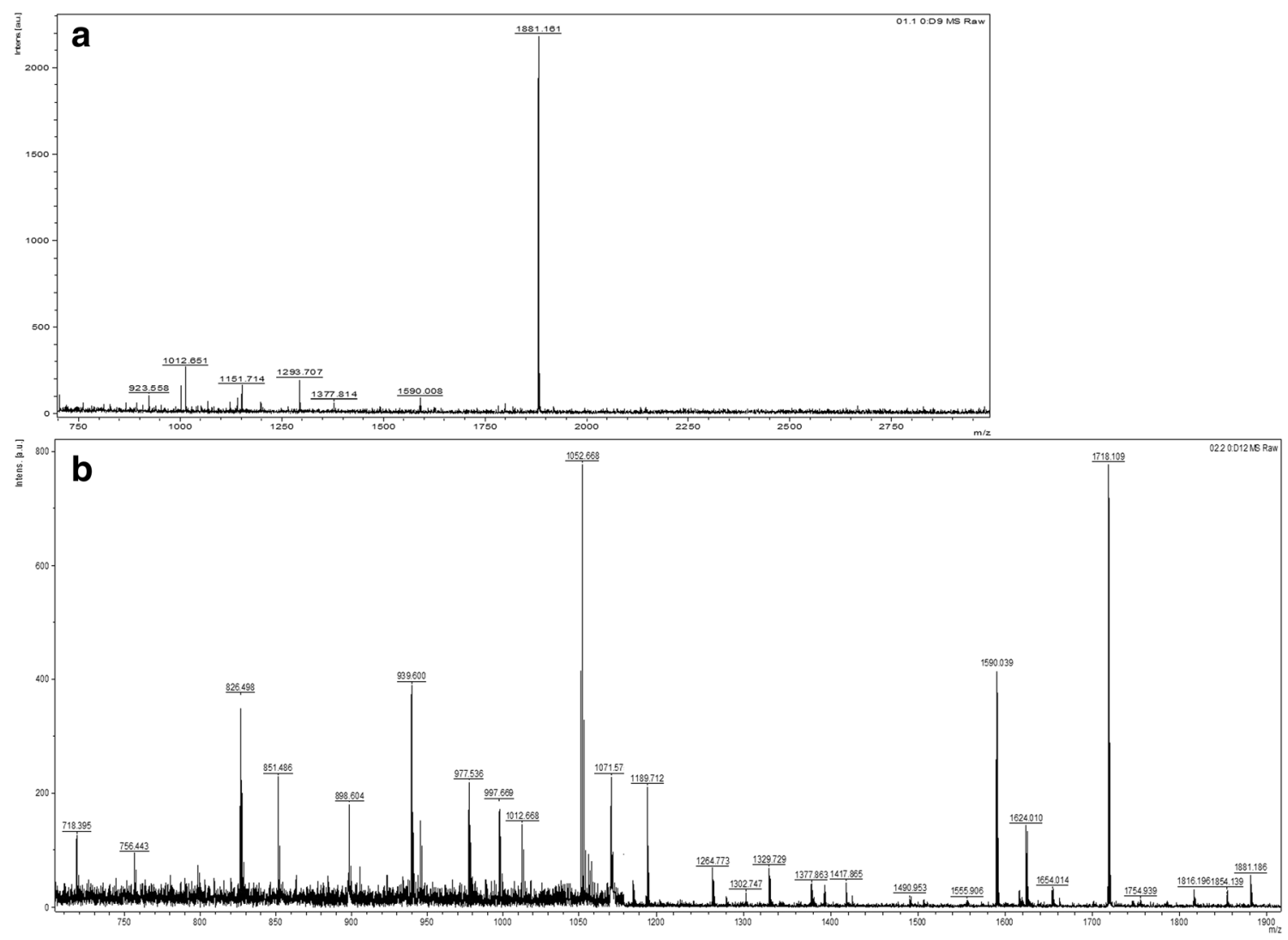

Fig. 4 MALDI-TOF-MS profile of peptide extract from a pasteurized sheep's milk and $\mathbf{b}$ fermented sheep's milk 
Table 2 Peptides identified in the water-soluble extracts of kefirtype fermented sheep's milk according to the mass spectrometry data compared to literature

\begin{tabular}{|c|c|c|c|}
\hline Measured value (Da) & Sequence & Origin & Activity \\
\hline 756 & DKIHPF & $\beta$-casein $47-52^{\mathrm{a}}$ & Antihypertensive ${ }^{\mathrm{b}}$ \\
\hline 898 & IESPPEIN & $\mathrm{K}$-casein $153-160^{\mathrm{c}}$ & \\
\hline 977 & RDMPIQAF & $\beta$-casein $183-190^{\mathrm{c}}$ & \\
\hline 997 & LQDKIHPF & $\beta$-casein $45-52^{\mathrm{c}}$ & Antihypertensive ${ }^{b}$ \\
\hline 1052 & NENLLRFF & $\alpha_{\mathrm{S} 1}$-casein $17-24^{\mathrm{c}}$ & \\
\hline 1090 & RDMPIQAFL & $\beta$-casein $183-191^{\mathrm{c}}$ & \\
\hline 1099 & ILQWQVLSN & K-casein $73-81^{\mathrm{d}}$ & \\
\hline 1136 & KVPQLEIVPN & $\alpha_{\mathrm{S} 1}$-casein $105-114^{\mathrm{c}}$ & Antihypertensive ${ }^{b}$ \\
\hline 1140 & RPKHPIKHQ & $\alpha_{\mathrm{S} 1}$-casein $16-24^{\mathrm{a}}$ & Antihypertensive ${ }^{b}$ \\
\hline 1151 & MESTEVFTK S3(phospho) & $\alpha_{\mathrm{S} 2}$-casein $141-149^{\mathrm{c}}$ & \\
\hline 1173 & YQQKPVALIN & $\mathrm{K}$-casein $43-52^{\mathrm{c}}$ & \\
\hline 1329 & ARHPHPHLSFM & K-casein 96-106 & \\
\hline 1392 & QEPVLGPVRGPFP & $\beta$-casein $194-206^{\mathrm{c}}$ & Antioxidant $^{\mathrm{e}}$ \\
\hline 1555 & YQEPVLGPVRGPFP & $\beta$-casein $193-206^{\mathrm{c}}$ & Antioxidant $^{\mathrm{e}}$ \\
\hline 1718 & QEPVLGPVRGPFPIIV & $\beta$-casein $194-209^{c}$ & Antioxidant ${ }^{\mathrm{e}}$ \\
\hline 1881 & YQEPVLGPVRGPFPIIV & $\beta$-casein $193-209^{c}$ & Antioxidant $^{\mathrm{e}}$ \\
\hline
\end{tabular}

Peptide molecular weight range from 700 to 3000 Da. Literature used: $a=$ Ebner et al. [6]; b = Papadimitrou et al. [17]; c = Robert et al. [39]; d = Hernandez-Ledesma et al. [38]; and e = Farvin et al. [37]

Table 3 Results of antimicrobial and antioxidant activity by water-soluble peptides from pasteurized and fermented sheep's milk

\begin{tabular}{|c|c|c|c|c|c|c|c|}
\hline & & \multicolumn{6}{|l|}{ Samples $^{\mathrm{c}}$} \\
\hline & & T0 & $\mathrm{T} 1$ & $\mathrm{~T} 7$ & T14 & $\mathrm{T} 21$ & $\mathrm{~T} 28$ \\
\hline \multicolumn{8}{|c|}{ Antimicrobial activity ${ }^{\mathrm{a}}(\%)$} \\
\hline \multirow[t]{7}{*}{ Strains } & Escherichia coli ATCC 25922 & - & $80.60 \pm 0.08$ & 100 & $95.8 \pm 0.01$ & $99.97 \pm 0.03$ & 100 \\
\hline & $\begin{array}{l}\text { Klebsiella pneumoniae ATCC } \\
29665\end{array}$ & - & - & $99.98 \pm 0.02$ & $93.0 \pm 0.02$ & $97.50 \pm 0.01$ & $83.50 \pm 0.02$ \\
\hline & $\begin{array}{l}\text { Pseudomonas aeruginosa ATCC } \\
27853\end{array}$ & $49.00 \pm 0.01$ & $83.7 \pm 0.01$ & 100 & $99.98 \pm 0.02$ & $99.97 \pm 0.03$ & $98.20 \pm 0.02$ \\
\hline & Enterococcus faecalis ATCC 6057 & - & $99.97 \pm 0.03$ & 100 & $99.99 \pm 0.01$ & $94.50 \pm 0.01$ & 100 \\
\hline & Bacillus cereus ATCC 33019 & $87.80 \pm 0.03$ & - & 100 & $94.5 \pm 0.01$ & $99.96 \pm 0.04$ & 100 \\
\hline & Bacillus subtilis ATCC 6633 & $24.80 \pm 0.14$ & - & 100 & $93.00 \pm 0.03$ & $99.96 \pm 0.04$ & 100 \\
\hline & Staphylococcus aureus ATCC 6538 & - & - & 100 & $92.00 \pm 0.04$ & $99.98 \pm 0.02$ & 100 \\
\hline \multicolumn{8}{|c|}{ Antioxidant activity expressed in percentage of scavenging $(\%)$} \\
\hline \multicolumn{8}{|c|}{$\mathrm{ABTS}^{\mathrm{b}}$ method } \\
\hline \multirow[t]{7}{*}{ Incubation time (min) } & 6 & $5.73 \pm 0.38$ & $11.01 \pm 0.60$ & $9.22 \pm 0.86$ & $11.49 \pm 0.68$ & $12.93 \pm 0.67$ & $23.51 \pm 2.52$ \\
\hline & 30 & $8.75 \pm 0.43$ & $12.88 \pm 1.07$ & $13.12 \pm 0.73$ & $12.08 \pm 1.10$ & $17.84 \pm 0.55$ & $27.67 \pm 1.45$ \\
\hline & 60 & $11.23 \pm 0.19$ & $13.26 \pm 0.60$ & $13.96 \pm 0.56$ & $15.91 \pm 1.13$ & $22.75 \pm 0.38$ & $30.30 \pm 3.06$ \\
\hline & 90 & $12.07 \pm 1.21$ & $14.43 \pm 3.21$ & $15.98 \pm 2.03$ & $15.74 \pm 2.22$ & $25.57 \pm 0.12$ & $34.19 \pm 3.29$ \\
\hline & 120 & $13.30 \pm 0.57$ & $8.07 \pm 1.27$ & $16.22 \pm 0.41$ & $16.67 \pm 2.31$ & $26.91 \pm 0.26$ & $37.36 \pm 2.31$ \\
\hline & 150 & $13.48 \pm 0.33$ & $16.52 \pm 0.67$ & $18.38 \pm 1.12$ & $18.30 \pm 1.16$ & $28.23 \pm 0.47$ & $39.09 \pm 3.62$ \\
\hline & 180 & $15.91 \pm 1.67$ & $19.50 \pm 0.67$ & $19.73 \pm 1.12$ & $18.77 \pm 1.16$ & $31.17 \pm 0.47$ & $41.49 \pm 3.62$ \\
\hline \multicolumn{8}{|l|}{ DPPH method } \\
\hline \multirow{4}{*}{$\begin{array}{l}\text { WSP concentration } \\
\quad(\mathrm{mg} / \mathrm{mL})\end{array}$} & 25 & $36.09 \pm 2.00$ & $33.45 \pm 3.00$ & $25.40 \pm 0.01$ & $21.15 \pm 1.00$ & $20.80 \pm 1.00$ & $18.39 \pm 0.01$ \\
\hline & 12.5 & $31.26 \pm 4.00$ & $28.62 \pm 3.00$ & $34.25 \pm 1.00$ & $27.82 \pm 3.00$ & $24.94 \pm 1.00$ & $30.92 \pm 1.00$ \\
\hline & 6.25 & $38.16 \pm 0.01$ & $37.01 \pm 2.00$ & $28.39 \pm 2.00$ & $57.01 \pm 2.00$ & $51.38 \pm 1.00$ & $27.13 \pm 1.00$ \\
\hline & 3125 & $72.41 \pm 1.00$ & $55.40 \pm 0.01$ & $45.17 \pm 2.00$ & $42.41 \pm 3.00$ & $54.94 \pm 1.00$ & $50.34 \pm 4.00$ \\
\hline
\end{tabular}

${ }^{\text {a }}$ Antimicrobial activity was used $25 \mathrm{mg} / \mathrm{mL}$ of WSP

${ }^{\mathrm{b}}$ Antioxidant activity was used $6.25 \mathrm{mg} / \mathrm{mL}$ of WSP (b)

${ }^{\mathrm{c}}$ Samples from pasteurized (T0), and fermented sheep's milk after storage at $4{ }^{\circ} \mathrm{C}$ for 1 (T1), 7 (T7), 21 (T21), and 28 days (T28) 
ATCC 6633 was observed, and this showed a high percentage inhibition $(87.80 \pm 0.03)$ for $B$. cereus.

This study showed that the peptides extracted from sheep milk fermented using kefir grains presented $100 \%$ inhibition of the growth of Escherichia coli ATCC 25922, Klebsiella pneumoniae ATCC 29665, Pseudomonas aeruginosa ATCC 27853, Bacillus cereus ATCC 33019, Bacillus subtilis ATCC 6633 and Staphylococcus aureus ATCC 6538 from the 7th to the 28th day of storage. The last analysis showed decreasing inhibition values, but these values were not significant.

\section{Antioxidant activity}

All peptide extracts obtained from sheep milk during storage presented antioxidant activity at concentrations of 3.125, 6.25, 12.5 and $20.0 \mathrm{mg} / \mathrm{mL}$, and the results are shown in Table 3. The peptide extracts presented 16 to $41.5 \%$ antioxidant activity according to the methodology. The highest value obtained $(41.5 \% \pm 3.6 \%)$ was from using the fermented milk on the 28th day of storage.

In the present study, the antioxidant capacity of peptides extracted from sheep milk fermented using kefir did not decrease at the end of the storage period. The percentage of antioxidant activity after fermentation was time dependent at weekly intervals and the highest value was observed on the 28th day.

Moreover, we observed in Table 3 that the antioxidant activity of peptides against the DPPH radical is able to scavenge the free radicals. Samples with 6.25 and $3.125 \mathrm{mg} / \mathrm{mL}$ presented the highest antioxidant ability.

\section{Discussion}

The microbiology characterization of the present study is consistent with the data obtained by Moslehishadet al. [31] who studied the antihypertensive and antioxidants activities of the peptide fractions from fermented bovine and camel milk by Lactobacillus rhamnosus. These authors reported that even during storage of the fermented milk in the cold, the proteolytic activity of lactic acid bacteria remains, thus releasing peptides which act as growth factors, and this maintains the culture stable for a period. Moreover, the release of peptides and amino acids as the nutrient supply by the proteolytic system of L. rhamnosus may explain the viability and minimal decline in the cell population [31-33]. The yeast count in kefir ranges from 3 to $7 \log _{10} \mathrm{CFU} / \mathrm{mL}$ according to Grønnevik, Falstad and Narvhus [25]. However, cow milk fermented using kefir yeast by Montanuci, Garcia and Prudencio [34] exhibited levels as high as those observed in our study ( 8 $\log _{10} \mathrm{CFU} / \mathrm{mL}$ ) on the first day of fermentation.

An evaluation was made of the shelf life of the sheep's milk fermented by kefir grains which was developed as a product for our study. The results showed that this milk remained safe from contaminating microorganisms because the presence of coliforms and Escherichia coli was not detected throughout the 28 days of storage (data not shown). This result is in accordance with Grønnevik, Falstadand, and Narvhus [25] who studied Norwegian kefir during storage, and Chifíriuc, Cioaca, and Lazar [15] who performed an in vitro assay of the antimicrobial activity of kefir against bacterial and fungal strains.

The physicochemical results show $\mathrm{pH}$ decreased and acidity increased during the fermentation of the milk by kefir grains, which, according to Magalhães et al. [35], mainly reflected that the microbial populations of kefir grains produced organic acids, alcohol, $\mathrm{CO}_{2}$ and volatile compounds. The production of lactic acid associated with the metabolism of lactic acid bacteria has an inhibitory effect on pathogenic microorganisms and on the spoilage of fermented milk prepared using kefir [36]. Furthermore, this acidity aids absorption, because it can release free macromolecules and minerals and it prevents possible foodborne illnesses.

The differences in the profiles of RP-HPLC chromatograms of the fermented milk is because of complex microbiota present on kefir grains, which produce peptides from proteins in milk [25]. Papadimitriou et al. [17] used RPHPLC to analyze the samples of fermented milk and yogurt produced from sheep milk using Lactobacillus delbrueckii subsp. bulgaricus, Streptococcus thermophilus and Lactobacillus paracasei subsp. paracasei. They obtained peptides profiles for samples stored for 2, 10 and 26 days, and the results were consistent with those obtained in our study. Indeed, the data for the storage time obtained in their study were consistent with the results presented here, as the profiles obtained for the samples after 7 and 28 days of storage were similar in both studies.

Maldi-ToF spectrometry of the fermented milk shared approximately half of the signals, including the peptides at $\mathrm{m} / \mathrm{z}$ $1012,1140,1151,1377,1590$ and 1881 suggesting similarities with the original milk and differences in the release of peptides, thereby reflecting the fermentation process. Previous studies [6, 17, 37-39] indicate that the peptides that exhibit antihypertensive activity are those of lower molecular weight (756 to 1140) and those that link antioxidant activity are those of a molecular weight between 1392 and 1881. Also, the presence of four peptides may be observed probably with antioxidant activity, and all of which were obtained from $\beta$-casein. Furthermore, peptides probably with antihypertensive activity may be interconnected.

The antimicrobial activity of pasteurized milk is in accordance with Ismaiel, Ghaly and El-Naggar [40]. They described the antimicrobial activity of the peptides extracted from pasteurized milk, concerning the bacteria mentioned above in cow's milk. The peptides extracted from sheep milk fermented using kefir grains presented inhibition of the growth of diverse microbial pathogens. Chifíriuc, Cioaca and Lazar [15] examined kefir-type fermented cow's milk for 24 and $48 \mathrm{~h}$ preserved for 7 days at $4-8{ }^{\circ} \mathrm{C}$ and the antimicrobial activity was examined using an adapted in vitro disk diffusion method with fresh 
microbial cultures of Bacillus subtilis spp. spizizenii ATCC 6633, Staphylococcus aureus ATCC 6538, Enterococcus faecalis ATCC 29212, Escherichia coli ATCC 8739, Salmonella enteritidis ATCC 13076, Pseudomonas aeruginosa ATCC 9027 and Candida albicans ATCC 10231, resulting in similar data compared with B. subtilis, S. aureus, E. coli, E. faecalis and $S$. enteritidis in all tested samples.

The data revealed that the fermented milk increases the degree of proteolysis, and this generates an accentuated concentration of peptides during cold storage. This outcome reflected a high level of antioxidant activity at the end of the storage period, which is consistent with the results of Virtanen et al. [41] and reveals the relationship between the development of antioxidant activity and a high degree of proteolysis. The results obtained in our study were similar to those of Moslehishad et al. [31] who examined antioxidant activity using the ABTS radical from aqueous peptide extracts from fermented cow's and camel's milk against Lactobacillus ramnosus PTCC 1637, and observed that the peptide extracts with the highest antioxidant activity were those examined at the end of the storage time ( 21 days). These authors suggested that it is not only the size of the peptides but also their nature and composition, which are not similar in fermented bovine and camel's milk, that play an important role in quenching the ABTS radical and in promoting the efficiency of the antioxidant.

Other studies have reported that peptides from sheep milk showed ABTS radical scavenging activity. Corrêa et al. [42] reported the high ABTS scavenging activity $(83.4 \pm 0.75 \%)$ of bovine milk caseinate after hydrolysis for $4 \mathrm{~h}$ with one protease extracted from Bacillus sp. P7. Silva et al. [43] reported that the peptides in the aqueous peptide extract of sheep's milk cheeses, released after cleavage of the Leu190Tyr191 peptide bond of $\beta$ casein presented ABTS radical scavenging activity.

Meira et al. [44] conducted antioxidant activity tests using the ABTS radical with aqueous peptide extracts from a variety of sheep's milk cheeses produced in southern Brazil and Uruguay, and the results suggested that the antioxidant activity increased when the length of time allowed for the cheeses to ripen was increased. These data are consistent with our study with regard to the results obtained related to storage time.

Results of the tests realized with ABTS and DPPH radicals showed different values for antioxidant activity. These data are similar to those in previous studies which examined peptides in sheep's milk [42, 43]. According to Corrêa et al. [42], the distinctive behavior of protein hydrolysates in ABTS and DPPH radical scavenging assays could reflect the stereoselectivity of different radicals; the various peptides present in the sample which are able to react with and quench different radicals; and the different stoichiometry of the reactions between the antioxidant compounds in hydrolysates and the ABTS and DPPH radicals.

Moreover, the assay samples had high concentrations of $\mathrm{DPPH}$, suggesting that the antioxidant activity with ABTS is more sensitive and appropriate for the measurement of the antioxidant activity of peptide extracts of sheep's milk fermented using kefir grains.

\section{Conclusions}

There is a worldwide need for new dairy products that can help to meet the growing demand for food. People are increasingly demanding food quality. This is not only in terms of food being nutritious but also that it contains natural substances that can regulate basic bodily functions and can do so without the use of chemicals. Thus, this paper presents a new product for the dairy industry. The main ingredient is sheep's milk, which in some ways is superior to bovine milk. Kefir grains are added to this milk and the mixture is left to ferment. The benefits of using kefir grains are that they are able to ferment sugars, degrade proteins, and generate bioactive compounds and it is by using kefir grains that these properties are made inherent in the product manufactured.

Kefir-type fermented sheep's milk showed the characteristics of a nutritionally complete product and possesses peptides with antimicrobial and antioxidant activity. These activities help the body to defend itself against pathogens and deleterious effects.

\section{Compliance with Ethical Standards}

Conflict of Interest The authors declare that they have no conflicts of interest.

\section{References}

1. John S M, Deeseenthum S (2015) Properties and benefits of kefira review. Songklanakarin J Sci Technol 37: 275-282

2. Irigoyen A, Arana I, Castiella M et al (2005) Microbiological, physicochemical, and sensory characteristics of kefir during storage. Food Chem 90(4):613-620. https://doi.org/10.1016/j. foodchem.2004.04.021

3. Satir G, Seydim G (2016) How kefir fermentation can affect product composition? Small Rumin Res 134:1-7

4. Miguel MGCP, Cardoso PG, Lago LA, Schwan RF (2010) Diversity of bacteria present in milk kefir grains using culturedependent and culture-independent methods. Food Res Int 43(5): 1523-1528. https://doi.org/10.1016/j.foodres.2010.04.031

5. Nielsen B, Gurakan GC, Unlu G (2014) Kefir: a multifaceted fermented dairy product. Probiotics Antimicrob Proteins 6:123-135

6. Ebner J, Ayșe AA, Fedorova M et al (2015) Peptide profiling of bovine kefir reveals 236 unique peptides released from caseins during its production by starter culture or kefir grains. J Proteomics 117:41-57

7. Cogulu D, Topaloglu-Ak A, Caglar E, Sandalli N, Karagozlu C, Ersin N, Yerlikaya O (2010) Potential effects of a multistrain probiotic-kefir on salivary Streptococcus mutans and Lactobacillus spp. J Dent Sc 5(3):144-149. https://doi.org/10. 1016/S1991-7902(10)60021-9

8. Fahmy HA, Ismail AFM (2015) Gastroprotective effect of kefir on ulcer induced in irradiated rats. J Photochem Photobiol B 144:8593. https://doi.org/10.1016/j.jphotobiol.2015.02.009 
9. Bekar O, Yilmaz Y, Gulten M (2011) Kefir improves the efficacy and tolerability of triple therapy in eradicating Helicobacter pylori. J Med Food 14(4):344-347. https://doi.org/10.1089/jmf.2010.0099

10. Thoreux K, Schmucker DL (2001) Kefir milk enhances intestinal immunity in young but not old rats. J Nutr 13:807-812

11. Urdaneta E, Barrenetxe J, Aranguren P, Irigoyen A, Marzo F, Ibáñez FC (2007) Intestinal beneficial effects of kefirsupplemented diet in rats. Nutr Res 27(10):653-658. https://doi. org/10.1016/j.nutres.2007.08.002

12. Franco MC, Golowczyc MA, De Antoni GL, Perez PF, Humen M, Serradell MA (2013) Administration of kefir-fermented milk protects mice against Giardia intestinalis infection. J Med Microbiol 62(Pt 12):1815-1822. https://doi.org/10.1099/jmm.0.068064-0

13. Friques AGF, Arpini CM, Kalil IC, Gava AL, Leal MA, Porto ML, Nogueira BV, Dias AT, Andrade TU, Pereira TMC, Meyrelles SS, Campagnaro BP, Vasquez EC (2015) Chronic administration of the probiotic kefir improves the endothelial function in spontaneously hypertensive rats. J Transl Med 13(1):390. https://doi.org/10.1186/ s12967-015-0759-7

14. Li Y, Sadiq FA, Liu T et al (2015) Purification and identification of novel peptides with inhibitory effect against angiotensin Iconverting enzyme and optimization of process conditions in milk fermented with the yeast Kluyveromyces marxianus. J Funct Foods $16: 278-288$

15. Chifiriuc MC, Cioaca AB, Lazar V (2011) In vitro assay of the antimicrobial activity of kephir against bacterial and fungal strains. Anaerobe 17:433-435

16. Liu JR, Chen MJ, Lin CW (2005) Antimutagenic and antioxidant properties of milk-kefir and soymilk-kefir. J Agric Food Chem 53(7):2467-2474

17. Papadimitriou CG, Vafopoulou-Mastrojiannaki A, Silva SV et al (2007) Identification of peptides in traditional and probiotic sheep milk yoghurt with angiotensin I-converting enzyme (ACE)-inhibitory activity. Food Chem 105(2):647-656. https://doi.org/10.1016/ j.foodchem.2007.04.028

18. Politis I, Theodorou G (2016) Angiotensin I-converting (ACE)-inhibitory and anti-inflammatory properties of commercially available Greek yoghurt made from bovine or ovine milk: a comparative study. Int Dairy J 58:46-49

19. Korhonen H, Pihlanto A (2007) Technological options for the production of health-promoting proteins and peptides derived from milk and colostrum. Curr Pharm Des 13:8429-8434

20. Dallas DC, Citerne F, Tian T et al (2016) Peptidomic analysis reveals proteolytic activity of kefir microorganisms on bovine milk proteins. Food Chem 197:273-284

21. Rahmawatia IS, Suntornsuk B (2016) Effects of fermentation and storage on bioactive activities in milks and yoghurts. Procedia Chem 18:53-62

22. Akalin AS (2014) Dairy-derived antimicrobial peptides: action mechanisms, pharmaceutical uses and production proposals. Trends Food Sci Tech 36(2):79-95. https://doi.org/10.1016/j.tifs.2014.01.002

23. AOAC (2002) Official methods of analysis of the Association of Official Analytical Chemists. AOAC International, Washington

24. Santos DM, Pedroso MM, Costa LM et al (2005) A new procedure for bovine milk digestion in a focused microwave oven: gradual sample addition to pre-heated acid. Talanta 65(2):505-510. https:// doi.org/10.1016/j.talanta.2004.07.013

25. Grønnevik H, Falstad M, Narvhus JA (2011) Microbiological and chemical properties of Norwegian kefir during storage. Int Dairy J 21:601-606

26. Pritchard SR, Phillips M, Kailasapathy K (2010) Identification of bioactive peptides in commercial cheddar cheese. Food Res Int 43: $1545-1548$

27. Re R, Pellegrini N, Proteggente A et al (1999) Antioxidant activity applying an improved ABTS radical cation decolorization assay. Free Radic Biol Med 26:1231-1237
28. Silva RA, Lima MSF, Viana JBM, Bezerra VS, Pimentel MCB, Porto ALF, Cavalcanti MTH, Lima Filho JL (2012) Can artisanal "Coalho" cheese from Northeastern Brazil be used as a functional food? Food Chem 135(3):1533-1538. https://doi.org/10.1016/j. foodchem.2012.06.058

29. Brand-Williams W, Cuvelier ME, Berset C (1995) Use of a free radical method to evaluate antioxidant activity. LWT Food Sci Technol 28(1): 25-30. https://doi.org/10.1016/S0023-6438(95)80008-5

30. Fukumoto LR, Mazza G (2000) Assessing antioxidant and prooxidant activities of phenolic compounds. J Agr Food Chem 48(8):3597-3604

31. Moslehishad M, Ehsani MR, Salami M, Mirdamadi S, Ezzatpanah H, Naslaji AN, Moosavi-Movahedi AA (2013) The comparative assessment of ACE-inhibitory and antioxidant activities of peptide fractions obtained from fermented camel and bovine milk by Lactobacillus rhamnosus PTCC 1637. Int Dairy J 29(2):82-87. https://doi.org/10.1016/j.idairyj.2012.10.015

32. Pastar I, Tonic I, Golic N et al (2003) Identification and genetic characterization of a novel proteinase, PrtR, from the human isolate Lactobacillus rhamnosus BGT10. Appl Environ Microbiol 69(10): 5802-5811. https://doi.org/10.1128/AEM.69.10.5802-5811.2003

33. Savijoki K, Ingmer H, Varmanen P (2006) Proteolytic systems of lactic acid bacteria. Appl Microbiol Biotechnol 71(4):394-406. https://doi.org/10.1007/s00253-006-0427-1

34. Montanuci FD, Garcia S, Prudencio SH (2010) Sensory characterization and acceptance of sweetened full fat and low fat kefir with inulin. Braz J Food Technol 8:79-90

35. Magalhães KT, Dragone G, Pereira GVM et al (2011) Comparative study of the biochemical changes and volatile compound formations during the production of novel whey-based kefir beverages and traditional milk kefir. Food Chem 126:249-253

36. Magalhães KT, Pereira GVM, Campos CR, Dragone G, Schwan RF (2011) Brazilian kefir: structure, microbial communities and chemical composition. Braz J Microbiol 42(2):693-702. https:// doi.org/10.1590/S1517-83822011000200034

37. Farvin KHS, Baron CP, Nielsen NS et al (2010) Antioxidant activity of yoghurt peptides: Part 1-in vitro assays and evaluation in $\omega-3$ enriched milk. Food Chem 123(4):1081-1089. https://doi.org/10. 1016/j.foodchem.2010.05.067

38. Hernández-Ledesma B, Miralles B, Amigo L, Ramos M, Recio I (2005) Identification of antioxidant and ACE-inhibitory peptides in fermented milk. J Sci Food Agr 85(6):1041-1048

39. Robert MC, Razaname A, Mutter M, Juillerat MA (2004) Identification of angiotensin-I-converting enzyme inhibitory peptides derived from sodium caseinate hydrolysates produced by Lactobacillus helveticus NCC 2765. J Agr Food Chem 52(23): 6923-6931

40. Ismaiel AA, Ghaly MF, El-Naggar AK (2011) Milk kefir: ultrastructure, antimicrobial activity and efficacy on aflatoxin B1 production by Aspergillus flavus. Curr Microbiol 62(5):1602-1609. https://doi.org/10.1007/s00284-011-9901-9

41. Virtanen T, Pihlanto A, Akkanen S, Korhonen H (2007) Development of antioxidant activity in milk whey during fermentation with lactic acid bacteria. J Appl Microbiol 102(1):106-115. https://doi.org/10.1111/j.1365-2672.2006.03072.x

42. Corrêa APF, Daroit DJ, Coelho J et al (2011) Antioxidant, antihypertensive and antimicrobial properties of ovine milk caseinate hydrolyzed with a microbial protease. J. Sci Food Agr 91:2247-2254

43. Silva SV, Pihlanto A, Malcata FX (2006) Bioactive peptides in ovine and caprine cheese like systems prepared with proteases from Cynara cardunculus. J Dairy Sci 89(9):3336-3344. https://doi.org/ 10.3168/jds.S0022-0302(06)72370-0

44. Meira SMM, Daroit DJ, Helfer VE, Corrêa APF, Segalin J, Carro S, Brandelli A (2012) Bioactive peptides in water-soluble extracts of ovine cheeses from Southern Brazil and Uruguay. Food Res Int 48(1):322-329. https://doi.org/10.1016/j.foodres.2012.05.009 